\title{
Industri 4.0 dan Pendidikan (Upaya Perguruan Tinggi dalam Mempersiapkan Kelulusan yang Siap Terhadap Gencaran Serangan Revolusi Industri 4.0)
}

\author{
Nia Yunia Sari, M.Pd.I \\ Institut Agama Islam Riyadlotul Mujahidin Ngabar Ponorogo \\ Sariyunia01@gmail.com
}

\section{Abstract}

The society will always continue to change along with the times. And changes that occur in these communities are natural and unavoidable, although that the changes between one community and another will be different. Likewise with the modernization process. The modernization in certain societies will be different from other societies both in the process and in acceptance depending on the needs and desires of the community itself. Changes that occur in these societies are modernization process that will handcuff the community to consumerist culture, hedonism and others. Modernization is a form of society social change from a traditional society to a developed society following the development of other society which are considered to be more advanced and developing first. Era 4.0 is where the current development are running so fast and rapid. Era 4.0 brought much of changes with all its effect. The world community is always changing so fast. The change was dramatic at exponential speed. Changes that are very influential in several sektors of human life. And nothing can be separated from this change. The entry of the 4.0 era in people's lives is colored with artificial intelligence, the era of super computers, genetic engineering, nanothecnology, innovation, etc. where sophisticated technology such as the internet of 
things, wearables, robotic and 3D printing enters all sektors of the industri and involves various stakeholders ranging from institution, governments, industri association, businesses, technology providers, research institutions and also education. The world of education is also inseparable from the grip of the 4.0 era modernization. Now a days, education runs fast in catching up with the times, following modernization. However, with this relity the community must be smart in choosing which of the modernization processes will be able to change society for the better, so that the benefits of modernization can be felt positively.

Keywords: Education, College, Industrial Revolution

\section{Abstrak}

Masyarakat senantiasa akan terus berubah seiring dengan perkembangan zaman, dan perubahan yang terjadi dalam masyarakat tersebut merupakan hal yang wajar dan tidak dapat dihindari, walaupun perubahan antara masyarakat satu dengan yang lainnya akan berbeda. Demikian juga dengan proses modernisasi. Modernisasi pada masyarakat tertentu akan berbeda dengan masyarkat yang lain baik dari prosesnya maupun pada penerimaannya tergantung pada kebutuhan dan keinginan dari masyarakat itu sendiri. Perubahan yang terjadi dalam masyarakat tersebut adalah proses modernisasi yang akan membelenggu masyarakat pada budaya konsumtif, hedonism dan lainnya. Modernisasi merupakan salah satu bentuk perubahan sosial masyarakat dari masyarakat tradisional menuju masyarakat maju mengikuti perkembangan masyarakat lainnya yang dianggap lebih du maju dan berkembang. Era 4.0 adalah dimana perkembangan zaman begitu cepat dan pesat. Era 4.0 membawa begitu banyak perubahan dengan segala pengaruhnya. Masyarakat dunia pun senantiasa berubah dengan begitu cepat. Perubahan itu sangat dramatis pada kecepatan 
eksponensial. Perubahan yang sangat berpengaruh dalam beberapa sektor kehidupan manusia. Dan tidak ada yang dapat terlepas dari perubahan ini. Masuknya era 4.0 dalam kehidupan masyarakat diwarnai dengan artificial intelligence atau kecerdasan buatan, era super computer, rekayasa genetika, teknologi nano, inovasi dll. Dimana teknologi canggih seperti internet of things, wearables, robotica dan 3D printing masuk dalam segala sektor industri dan melibatkan berbagai pemangku kepentingan mulai dari dari institusi, pemerintah, asosiasi industri, pelaku usaha, penyedia tekhnologi, lembaga riset dan juga pendidikan. Dunia pendidikan juga tidak terlepas dari cengkraman tangan modernisasi era 4.0 ini. Saat ini, pendidikan berlari dengan cepat mengejar perkembangan zaman, mengikuti modernisasi. Akan tetapi, dengan kenyataan ini masyarakat pun harus harus cerdas dalam memilih mana dari proses modernisasi tersebut yang akan dapat merubah masyarakat kea rah yang lebih baik, sehingga manfaat darI modernisasi dapat dirasaklan secara positif.

Keywords: Pendidikan, Perguruan Tinggi, Revolusi Industri

\section{Pendahuluan}

Perkembangan zaman saaat ini mampu mempengaruhi dan merubah cara dan gaya hidup, cara bekerja, cara berhubungan satu sama lain. Dampak kemajuan tekhnologi pun berimbas langsung pada setiap industri yang ada, karena tidak bisa di pungkiri bahwa tekhnologi tidak bisa dipisahkan dengan berbagai industri yang ada. Perkembangan zaman membawa perubahan yang sangat besar.

Akhir-akhir ini, "Industri 4.0" sering terdengar di telinga masyarakat Indonesia bahkan masyarakat dunia. Karena industri 4.0 ini telah masuk dan merasuk dalam segala aspek kehidupan masyarakat serta membawa perubahan yang begitu berdampak. Akan tetapi, perubahan yang terjadi dalam 
kehidupan masyarakat saat ini hanya dapat dirasakan tanpa mengerti definisi, latar belakang, bahkan sejarah nya. Industri 4.0 seakan spontanitas masuk dalam setiap perubahan yang terjadi. Lalu. Apa itu industri 4.0?

\section{Definisi dan Sejarah Industri 4.0}

Industri 4.0 adalah industri yang menggabungkan antara tekhnologi otomatisasi dan cyber. Industri 4.0 adalah sebuah kondisi dimana terjadi perubahan besar-besaran dalam berbagai bidang lewat perpaduan tekhnologi dengan ditandai majunya tekhnologi dalam segala aspek. Industri 4.0 menjadi lompatan besar bagi berbagai sektor industri dunia dimana tekhnologi informasi dan komunikasi dimanfaatkan sepenuhnya tidak hanya dalam proses produksi saja, akan tetapi juga dalam keseluruhan rantai industri sehingga mampu melahirkan produk-produk baru, model bisnis baru, dengan basis digital untuk mencapai efesiensi tinggi dan kualitas produk yang baik. ${ }^{1}$

Dalam Revolusi industri telah terjadi beberapa tahap perubahan yang mana perubahan ini membawa dampak dan pengaruh yang sangat besar dalm kehidupan dibandingkan era revolusi industri sebelumnya, yaitu (1) Revolusi Industri 1.0 tahun 1784. Pada tahun ini ditandai dengan tumbuhnya mekanisasi dan energy berbasis uap dan air. Tenaga manusia dan hewan tergantikan dengan mesin. Mesin uap pada abad ke 18 adalah pencapaian yang tertinggi. (2) revolusi industri 2.0 tahun 1870. Perubahan ditandai dengan perkembangan energi listrik dan motor penggerak. Manufaktor dan produksi masal terjadi. Pesawat telelpon, mobil dan pesawat terbang menjadi pencapaian tertinggi. (3) Revolusi Industri 3.0 tahun 1969. Industri ini ditandai dengan tumbuhnya industri berbasis

${ }^{1}$ Marjuni, Revolusi Industri 4.0\&Society 5.0 ( What Is The Influence Of Industri 4.0 On Education.(Materi Workshop Pendidikan, 16 Maret 2019). 1 
elektronika, tekhnologi informasi, serta otomatisasi. Tekhnologi digital dan internet mulai dikenal.(4). Revolusi industri 4.0 tahun 2011. Ditandai dengan berkembangnya internet of things. Perkembangannya begitu cepat seperti yang dapat dirasakan saat ini. ${ }^{2}$

Dalam penerapannya. Industri 4.0 melibatkan berbagai pemangku kepentingan, mulai dari institusi, pemerintah, asosiasi industri, pelaku usaha, penyedia tekhnologi, lembaga riset dan juga pendidikan. Sebagai langkah awal, terdapat 5 industri yang menjadi focus implementasi, yakni: makanan dan minuman, tekstil dan pakaian, otomotif, kimia dan elektronik. Pada tahap ini revolusi industri berjalan secara eksponensial. Miliaran manusia akan terhubung mobile devices. ${ }^{3}$

Revolusi industri 4.0 memiliki ciri dan konsep yang berbeda dengan konsep industri sebelumnya. Ciri-ciri tersebut adalah: memiliki platform data yang besar; smart factory; cyber physical sistems; internet of things; interoperabilitas. Dari kelima konsep tersebut sangat menjelaskan bahwa pada industri ini memiliki konsep atau cirri yang berbeda dengan industriindustri sebelumnya. Dan ini merupakan perkembangan yang sangat cepat dari industri sebelumnya. Dengan kenyataan tersebut, maka akan banyak kehadiran tuntutan-tuntutan dalam mengikuti perkembangan industri ini, diantaranya adalah harus adanya antisipasi, harus beradaptasi dengan segala perubahan dan perkembangan yang terjadi dan memiliki strategi-strategi untuk menghadapi industri tersebut. ${ }^{4}$

\section{Pendidikan dan Industri 4.0}

${ }^{2}$ Ibid, 2

3 Aini Ummu Syukriya, Find Your Passion And Achieve Your Dream In 4.0 Era. Dalam Seminar Pendidikan IAIRM 15 Maret 2019. H. 6 ${ }^{4}$ Ibid, 8 
Suatu bangsa dapat dikatakan bangsa yang maju dan kuat apabila bangsa tersebut memiliki nilai-nilai dasar yang menjadi pedoman benar-benar termanifestasi dalam kehidupan, sehingga dalam kehidupan berbangsa, tidak akan ada hal-hal menyimpang yang akan terjadi. Dan eksistansi suatu bangsa dapat diukur dari sejauh mana bangsa tersebut mampu memberikan kontribusi nyata bagi kemajuan peradaban dunia. Salah satu bentuk kerja nyata dalam mewujudkan pencapaian nilai-nilai dasar yang menjadi pedoman dan ukuran kehidupan manusia dan juga kemampuan pencapaian kemajuan untuk perkembangan peradaban tersebut adalah dengan pendidikan.

Pendidikan memegang peranan yang sangat penting dalam kehidupan berbangsa karena fungsi pendidikan adalah mengembangkan kemampuan dan membentuk watak serta peradaban bermartabat dalam rangka mencerdaskan kehidupan bangsa. ${ }^{5}$ Bertujuan mengembangkan potensi manusia agar menjadi manusia yang berakhlak mulia, sehat, berilmu, cakap, kreatif, mandiri dan menjadi warga negara yang bertanggung jawab. ${ }^{6}$ Dari jabaran tersebut maka dapat diambil kesimpulan bahwa pendidikan merupakan suatu aktifitas manusia, pendidikan untuk menuntun membimbing, melatih mempebri pengajaran, pendidikan dilakukan dengan sengaja teratur dan terencana. Pendidikan merupakan perjanjian untuk merubah tingkah laku, watak manusia menuju manusia yang dewasa. ${ }^{7}$

Tujuan pendidikan menurut gambaran tentang nilai-nilai yang baik, luhur pantas, benar dan indah untuk kehidupan. Oleh

${ }^{5}$ Imam Rohani, "Pendidikan Karakter Dengan Pendekatan Tasawuf Modern Hamka Dan Tasawuf Transformatif Kontemporer," in Memperbincangkan Pemikiran Pendidikan Islam Dari Idealisme Substantif Hingga Konsep Aktual (Jakarta: Kencana, 2018).

${ }^{6}$ Undang-undang dasar republic Indonesia nomor 20 Tahuin 2003 tentang Sistem Pendidikan Nasional, pasal 3.

${ }^{7}$ Umar Tirtaraharja dan Sulo, Pengantar Pendidikan ( Jakarta: Rineka Cipta. 2005), 36. 
karena itu, tujuan pendidikan yaitu memberikan arahan kepada segenap kegiatan dan merupakan sesuatu yang ingin dicapai oleh kegiatan pendidikan. Tujuan pendidikan bersifat abstrak karena memuat nilai-nilai yang juga abstrak dalam semua struktur, peran, dan fungsi dimana sebuah sistem pendidikan berada. $^{8}$

Telah disebutkan bahwa industri 4.0 telah menjamur dalam segala aspek kehidupan masyarakat, tekhnologi menjadi tolak ukur dalam setiap aktifitas masyarakat tidak hanya masyarakat Indonesia saja akan tetapi juga masyarakat dunia. Perkembangan industri 4.0 merasuk begitu dalam dari segala bidang industri salah satunya adalah pendidikan. Pergerakan pertumbuhan dan perkembangan Pendidikan pada era ini menggeliat begitu cepat dan berlari seakan tiada henti. Banyak hal yang harus di ubah oleh Negara yang ingin maju dengan tingkat persaingan yang semakin ketat, salah satunya dari bidang pendidikan. Seiring perkembangan waktu dan zaman, terjadi perubahan tingkah laku dan prilaku manusia dari masa kemasa, begitu pula dengan sistem pendidikan. Sistem pendidikan adalah strategi atau metode yang digunakan dalam proses belajar mengajar untuk mencapai suatu tujuan agar peserta didik dapat secara aktif mengembangkan potensi yang ada.

Pendidikan era industri 4.0 merupakan istilah yang dipakai oleh para ahli pendidikan untuk menggambarkan dan meyelaraskan beragam cara dalam mengintegrasikan tekhnoligi cyber, baik secara fisik maupun tidak kedalam dunia pendidikan. Konsep ini merupakan lompatan dari perkembang pendidikan era industri 3.0 yang lebih mencakup pada ilmu saraf, psikologi kognitif dan tekhnologi pendidikan dengan

8 Akrimi Matswah, Pendidikan Gender Dalam Keluarga: Telaah Terhadap Hadis Tentang Relasi Laki-Laki Dan Perempuan Dalam Keluarga, Jurnal Al-Adabiyah, 2014) 77. 
menggunakan tekhnologi digital dan mobile berbasis web. Pendidikan era industri 4.0 merupakan fenomena yang timbul sebagai respon terhadap kebutuhan revolusi industri 4.0 dimana manusia dan mesin diselaraskan untuk memperoleh solusi, memecahkan berbagai masalah yang dihadapi serta menemukan berbagai kemumngkinan inovasi baru yang dapat dimanfaatkan bagi perbaikan kehidupan manusia modern.

\section{Pendidik di era industri 4.0}

Salah satu yang membedakan manusia dengan binatang adalah ilmu, oleh karena itu mencari ilmu merupakan suatu kewajiban dan dunia pendidikan adalah hal terpenting bagi identitas hidup manusia. Seperti yang dijelaskan oleh KH.M. Hasyim Asy'ari dalam salah satu karyanya Adab Al-Alim wa al-Muta'allim bahwasanya pendidikan itu penting sebagai sarana mencapai kemanusiaan, sehingga dia mampu menyadari siapa pencipta dan utnutk apa diciptakan. ${ }^{9}$

Pendidikan pada dasarnya adalah interaksi aktif antara seorang pendidik dengan peserta didik. Aktivitas ini memiliki tujuan mentransfer ilmu pengetahuan, mengubah tingkah laku dan menjadikan perubahan kea rah yang lebih baik.Proses pendidikan merupakan suatu kegiatan untuk membentuk kedewasaan pada diri seorang peserta didik. Semuia kegiatan dalam pendidikan merupaka suatu sistem yang saling berkaitan dalam sistem pendidikan yang integral. ${ }^{10} \mathrm{Di}$ sinilah peran seorang pendidik sangatlah mempengaruhi dan membantu agar peserta didik terhindar dari akhlak yang kurang baik, terhindar dari konflik berkepanjangan yang dapat menimbulkan perilaku menyimpang dalam kehidupan sehari-harinya. Dan seorang

${ }^{9}$ Muhammad Rifa'i, KH. Hasyim Asy’ari: Biografi singkat 18711947 (Jogjakarta: Garasi 2010), 75

${ }_{10}$ Syaiful Bahri Djamarah. Guru dan anak didik dalam interaksi edukatif. (Jakarta: PT.Rioneka Cipta, 2002). 22 
guru sekaligus dapat memberikan bimbingan untuk mengatasi segala permasalahan yang dihadapi oleh peserta didik.

Sistem pendidikan 4.0 telah bergaung kencang dalam kancah pendidikan Nasional maupun Internasional. Mau tidak mau, suka tidak suka suatu Negara yang menginginkan kemajuan dalam pendidikan juga harus menerima dan ikut berlari kencang mengejar kemajuan dalam era indurtri 4.0 ini. Pemerintah harus aktif menyediakan fasilitas yang memadai dalam menyongsong era pendidikan 4.0.

Pendidik memiliki peran yang sangat penting dalam dunia pendidikan. Sebagai garda terdepan dalam dunia pendidikan, pendidik harus terus mengembangkan kemampuan dalam menghadapi era industri 4.0 ini, jangan sampai seorang pendidik tertinggal perubahan zaman karena saat ini pendidik menghadapi peserta didik generasi milenial yang tidak asing dengan tekhnologi, dunia peserta didik zaman kekinian adalah zaman digital yang dikelilingi dengan elektonika. Peserta didik sudah sangat terbiasa dengan informasi dan tekhnologi.ini menunjukkan bahwa produk dalam suatu sekolah yang di loloskan harus mampu menjawab tantangan indutri 4.0. oleh karena itu, pendidik juga ditantang untuk mampu menguasai setiap perkembangan yang ada karena pentingnya peranan seorang pendidik dalam dunia pendidikan. Mengingat tantangan bagi seorang pendidik yang begitu besar, pendidik harus terus belajar meningkatkan kuantitas dan kualitas diri untuk mempersiapkan diri dalam menghadapi peserta didik generasi milenial.

Kualitas seorang pendidik harus sesuai dengan performa pendidik yang dibutuhkan dalam era industri 4.0 agar mampu mengimbangi peserta didik di era digital. Jika seorang pendidik tidak mau dan tidak mampu mengikuti perkembangan zaman, masih memegang teguh pendirian model pendidikan zaman lampau maka secara otomatis pendidik tersebut akan tertinggal 
jauh dari segala hal dan tentu akan mempengaruhi kualitas peserta didik.

Di Era revolusi industri 4.0 ini merupakan tantangan berat bagi seorang pendidik. jika seorang pendidik tidak mengubah cara mendidik dalam proses belajar mengajar. Maka, Beberapa tahun kedepan akan mengalami kesulitang yang luar biasa besar. Pendidikan dan pembelajaran yang syarat dengan muatan pengetahuan mengesampingkan muatan sikap dan ketrampilan sebagaimana terimplementasikan saat ini, akan menghasilkan peserta didik yang tidak mampu berkompetisi dengan mesin. Dominasi pengetahuan dalam pendidikan dan pembelajaran harus diubah terutama oleh seorang pendidik. agar kelakpeserta didik mampu mengungguli kecerdasan mesin sekaligus mampu bersikap bijak dalam menggunakan mesin untuk kemaslahatan.

\section{Peserta didik di era industri 4.0}

Peserta didik adalah anggota masyarakat yang berusaha mengembangkan potensi diri melalui proses pembelajaran yang tersedia pada jalur, jenjang dan jenias pendidikan tertentu. ${ }^{1}$ Peserta didik adalah mereka yang secara khusus diserahkan oleh kedua orangtuanya untuk mengikuti pembelajaran yang diselenggarakan di sekolah dengan tujuan untuk menjadi manusia. Manusia yang berilmu pengetahuan, berktrampilan, berpengalaman, berkpribadian, berakhlak mulia dan mandiri dalam kehidupan.

Peserta didik adalah organism yang unik yang berkembang sesuai dengan tahap perkembangannya. Perkembangan dari segala aspek kepribadiannya. Akan tetapi, tempo dan irama perkembangan masing-masing peserta didik pada setiap aspek tidak selalu sama. Peserta didik dikatakan sebagai sekelompok orang dengan usia tertentu dan tidak sama.

${ }^{11}$ UU Sisdiknas, pasal I ayat 4 
Berbicara mengenai peserta didik maka otomatis fikiran akan tertuju pada lingkungan sekolah, dimana sekolah adalah salah satu tempat para peserta didik mengembangkan dirinya baik secara fisikal atau emosional, baik secara jasmani maupun rohaninya. Karena peserta didik adalah masukan dalam sistem pendidikan yang selanjutnya diproses dalam proses pendidikan, sehingga menjadi manusia yang berkualitas sesuai tujuan orangtua yang menitipkan anaknya untuk menjadi salah seorang peserta didik disuatu sekolah maupun sesuai tujuan pendidikan nasional.

Lalu bagaimana seorang peserta didik di era industri pendidikan 4.0 ini? Pergulatan zaman menuju era 4.0 sangat mempengaruhi definisi seorang peserta didik. Peserta didik tidak hanya seseorang yang mengembangkan diri dalam ilmu pengetahuan saja, akan tetapi seorang peserta didik adalah ia yang mampu menggunakan segala fasilitas digital untuk memperoleh ilmu pengetahuan baru dan menciptakan suatu ketrampilan baru.Secara otomatis digitalism merasuk kedalam setiap jiwa-jiwa seorang manusia tak terkecuali peserta didik. Di era ini yang penuhi dengan tantangan dan persaingan. Setiap orang termasuk peserta didik dituntut untuk memiliki kualitas dan ketrampilan yang mumpuni dalam menjawab setiap tantangan zaman tersebut. Penguasaan keterampilan merupakan hal yang menjadi kewajiban bagi seorang peserta didik yang menjadi tulang punggung perjuangan dan harapan bangsa.

Dalam era revolusi industri 4.0 di bidang pendidikan, motivasi saja tidak cukup. Perkembangan ilmu pengetahuan dan tekhnologi yang sangat pesat memberikan dampak yang besar bagi seorang peserta didik. Banyak kemudahan dan inovasi dengan dukungan tekhnologi digital. Layanan menjadi lebih cepat dan efisien serta memiliki jangkauan koneksi yang sangat luas. Hidup seakan menjadi lebih mudah dan murah. Oleh karena itu, untuk memanfaatkan peluang dan menjawab 
tantangan revolusi industri 4.0 seorang peserta didik wajib memiliki beberapa ketrampilan, seperti: ketrampilan berfikir kritis dan inovatif, trampil bekerja dan menciptakan sesuatu, terampil belajar, terampil hidup, terampil meningkatkan diri, terampil mengelola informasi, terampil memanfaatkan tekhnologi, trampil dalam literasin data dan yang utama bagi peserta didik yaitu terampil menjalankan ketakwaan kepada Tuhan, karena ketrampilan utama adalah memilih mana yang boleh dilakukan dan tidak boleh dilakukan, mengendalikan diri dalam memilih sesuai norma agam masing-masing peserta didik.

Peserta didik dalam industri 4.0 adalah peserta didik yang harus berusaha keras dalam mewujudkan pendidikan yang berkualitas sesuai perkembangan zaman yaitu era digitalisasi. Harus menciptakan wujud konkret pendidikan yang mampu bersaing. Tantangan pasti akan dihadapi dalam setiap transisi inovasi dan tekhnologi. Peserta didik harus memiliki keberanian dan kesiapan mental jika tidak ingin tenggelam oleh era disrupsi ini.

\section{Perguruan tinggi di era industri 4.0}

Perguruan tinggi merupakan sebuah organisasi pendidikan yang terstruktur yang melibatkan masyarakat sebagai lingkungan utamanya. Perguruan tinggi juga merupakan strata teratas dalam jenjang pendidikan setelah pendidikan menengah atas. Secara structural sebagai satuan pendidikan tertinggi, perguruan tinggi tidak hanya menyelenggarakan pedidikan dijenjang pendidikan tinggi saja, akan tetapi perguruan tinggi juga melakukan penelitian dan melaksanakan pengabdian masyarakat sebagai upaya peningkatan kualitas diri baik secara teori maupun secara praktek sebagai bekal untuk kesiapan diri menghadapi masyarakat setelah selesai mengikuti program pendidikan. 
Berdasarkan kepemilikan, perguruan tinggi dibagi menjadi dua, yakni: perguruan tinggi negeri dan perguruan tinggi swasta. Di Indonesia perguruan tinggi dapat berbentuk akademik, politeknik,institut, univeritas, sekolah tinggi. Dengan program pendidikan berupa diploma, sarjana, magister, spesialis dan doctor. Perguruan tinggi dapat menyelenggarakan program akademik, profesi, dan/atau vocasi. Di Indonesia, dapat disebut sebagai perguruan tinggi apabila melaksanakan beberapa hal, yakni: bahwa perguruan tinggi adalah pelaksana pemerintah dalam pendidikan dan pengajaran di atas pendidikan menengah, melestarikan kebudayaan bangsa Indonesia secara ilmiah dengan mengikuti aturan UndangUndang yang berlaku, melaksanakan tri dharma perguruan tinggi (yaitu mengembangkan pendidikan dan pengajaran, penelitian dan pengabdian pada masyarakat), menyelenggarakan pembinaan pada civitas akademika dan hubungan baik dengan lingkungan. ${ }^{12}$

Perguruan tinggi adalah tahap akhir opsional dalam jenjang pendidikan. Lulusan perguruan tinggi adalah lulusan yang mempersiapkan diri untuk menghadapi dunia kerja. Persaingan ilmu pengetahuan dan ketrampilan di era tekhnologi mesin menuntut lulusan sebuah perguruan tinggi untuk terus maju dalam tantangan persaingan ini. Maka, salah satu tugas utama sebuah perguruan tinggi adalah bagaimana mencetak generasi, melahirkan lulusan yang siap berkompetisi, kuat terhadap setiap tantangan, mampu bersaing menghadapi perkembangan zaman.oleh karena itu, sebuah perguruan tinggi harus terus meningkatkan kualitas diri.

\section{Upaya perguruan tinggi dalam menyiapkan kelulusan yang kompetitif di era industri 4.0}

12 Agus Salam Rahmat dalam (http:// Downloads/4.0/ Pengertian Perguruan Tinggi, di akses tanggal 10 Oktober 2019) 
Perkembangan di era revolusi industri ditandai dengan pesatnya perkembangan tekhnologi. Pengetahuan dan Ketrampilan saja tidak akan berarti apa-apa jika tidak diimbangi dengan penguasaan tekhnologi. Pesatnya perkembangan zaman sangat mempengaruhi dunia kerja. Karena karakteristik pekerjaan saaat ini 90\% sangat dipengaruhi oleh oleh tekhnologi. Ilmu pengetahuan, kompetensi, ketrampilan dan technology menjadi satu kesatuan dalam segala aspek kehidupan di era 4.0 ini. Di era revolusi Industri integrasi pemanfaatan tekhnologi dan internet begitu canggih sangat mempengaruhi daya perubahan prilaku dunia usaha dan dunia industri, prilaku masyarakat dan konsumen yang ada.

Setidaknya ada tiga hal yang perlu diubah oleh Indonesia dari sisi edukasi. Pertama dan yang paling fundamental adalah merubah sifat dan pola fikir anak-anak muda. Kedua pentingnya peran sekolah dalam mengasah dan mengembangkan bakat generasi penerus bangsa. Ketiga adalah pengembangan kemampuan istitusi pendidikan tinggi untuk mengubah model pembelajaran yang sesuai dengan kebutuhan zaman. Banyak hal yang harus diubah oleh Negara yang menginginkan kemajuan. Hal ini juga berlaku untuk Indonesia. Terlebih saaat ini Indonesia tengah menghadapi era revolusi industri 4.0 dengan tingkat persaingan yang semakin ketat. Dari sejumlah perubahan yang harus dilakukan adalah dengan melakukan perbaikan SDM yang harus sangat diperhatikan. Perbaikan itu dapat dilaksanakan adalah salah satunya dengan cara mengubah metode pembelajaran dalam dunia pendidikan yang ada terutama pendidikan tinggi. Karena pendidikan tinggi merupakan jenjang terakhir dalam pendidikan yang selanjutnya akan mengarah pada dunia kerja.

Karakteristik industri 4.0 ditandai dengan adanya hubungan kuat antara manusia dengan mesin. Tantangan ini 
harus direspon dan ditanggapi dengan cepat dan tepat oleh seluruh pemangku kepentingan di lingkungan pendidikan terutama pendidikan tinggi agar mampu meningkatkan daya saing bangsa dalam dunia pendidikan dan dunia kerja.untuk itu pendidikan tinggi wajib merumuskan kebijakan-kebijakan strategis dalam keseluruhan aspek yang ada dalam perguruan tinggi itu sendiri, semisal: kurikulum, SDM, pengembangan cyber university, proses belajar mengajar di ruang kelas, inovasi baru, dll.

Menristekdikti menjelaskan ada lima elemen penting yang harus menjadi perhatian untuk mendorong pertumbuhan ekonomi dan daya saing baingsa dalam dunia pendidikan tinggi di era revolusi industri 4.0, yaitu:

1. Persiapan sistem pembelajaran yang lebih inovatif di perguruan tinggi seperti penyesuaian kurikulum pembelajaran dan meningkatkan kemampuan mahasiswa dalam hal data information technology (IT), operational technology (OT), internet of things dan big data analytic, menintegrasikan objek fisik, digital dan manusia untuk menghasilkan lulusan perguruan tinggi yang kompetitif dan terampil.

2. Rekonstruksi kebijakan kelembagaan pendidikan tinggi yang adaptif dan responsif terhadap revolusi 4.0 dalam mengembangkan transdisiplin ilmu dan program studi yang dibutuhkan. Mulai diupayakan cyber university dengan harapan menjadi solusi bagai peserta didik dari pelosok daerah untuk menjangkau pendidikan tinggi yang berkualitas.

3. Mempersiapkan SDM terkhusus bagi dosen dan peneliti untuk menopang kualitas dan kuantitas pendidikan, riset dan inovasi. 
4. Terobosan dalam riset dan pengembangan yang mendukung dan ekosistem untuk mendukung peningkatan kualitas dan kuantitas dalam perguruan tinggi

5. Terobosan inovasi dan perkuatan sistem inovasi untuk meningkatkan produktivitas industri dan meningkatkan perusahaan pemula berbasis teknologi. ${ }^{13}$

Dengan kelima elemen tersebut, maka dapat ditekankan bahwa perguruan tinggi memiliki andil yang sangat kuat dalam menciptakan manusia modern yang mampu mengikuti perkembangan zaman. Perguruan tinggi harus menciptakan inovasi-inovasi kreatif modern dengan memanfaatkan tekhnologi yang ada untuk meningkatkan kualitas dalam segala aspek yang terdapat dalam perguruan tinggi tersebut sehingga mampu melahirkan manusia-manusia yang akan mampu bersaing dalam menciptakan ktrampilan-kertrampilan dengan memanfaatkan digital dan tekhnologi dan mampu menciptakan kelulusan yang siap terhadap gencaran revolusi industri 4.0.

\section{Penutup}

Dunia pendidikan tidak terlewati oleh gencaran revolusi industri 4.0. Revolusi industri 4.0 menuntut manusia untuk mampu bersaing dalam segala aspek. Memanfaatkan ilmu pengetahuan, keterampilan dan kecakapan teknologi atau digital menjadi modal untuk menghadapi revolusi industri 4.0 ini. Seseorang yang tidak memiliki ilmu pengetahuan yang luas, tidak memiliki ktrampilan dan tidak mampu memanfaatkan tekhnologi yang ada, maka didalam modernisasi 4.0 adalah manusia yang tertinggal.

Perguruan tinggi merupakan jenjang pendidikan akhir dalam dunia pendidikan. Perguruan tinggi dituntut untuk terus meningkatkan diri agar melahirkan lulusan yang kompetitif.

${ }^{13}$ Sumber diambil dari www.ristekdikti.go.id/pengembangan-iptekdan-pendidikan-tinggi.di-era-revolusi-industri-4.0 
Gencaran revolusi industri 4.0 menekan perguruan tinggi untuk berupaya keras agar melahirkan generasi modern yang mampu berkompetisi untuk perkembangan hidup mereka. Lulusan dalam sebuah perguruan tinggi harus siap menghadapi hantaman keras revolusi industri 4.0. oleh karena itu, dalam penyelenggaraan pendidikan dan pengajaran serta penelitian dan pengabdian masyarakat, perguruan tinggi harus menanamkan kepada peserta didik untuk terus berfikir kritis dan memiliki inovasi atau ketrampilan, serta mampu memanfaatkan segala tekhnologi yang ada sebagai upaya untuk untuk mengahadapi gencaran revolusi industri 4.0 dalam dunia pendidikan.

\section{Referensi}

Bahri, Djamarah Syaiful, Guru Dan Anak Didik Dalam Interaksi Edukatif. Jakarta: PT.Rineka Cipta, 2002.

Jalal, F. Jalal, Kebijakan Pendidikan Dalam Profesionalisasi Pendidik Dan Tenaga Kependidikan Dalam Upaya Peningkatan Kualitas Pendidikan. Bandung: FIP UPI, 2005

Marjuni, Revolusi Industri 4.0\&Society 5.0 (What Is The Influence Of Industri 4.0 On Education (Materi Workshop Pendidikan, 16 Maret 2019)

Matswah, Akrimi. Pendidikan Gender Dalam Keluarga: Telaah Terhadap Hadis Tentang Relasi Laki-Laki Dan Perempuan Dalam Keluarga, Jurnal Al-Adabiyah, 2014 Muchsin, Bashori dkk. Pendidikan Islam Kontemporer. Bandung: Refika Aditama, 2009.

Rahmat, Agus Salam, dalam (http:// Downloads/4.0/ Pengertian Perguruan Tinggi. Diakses tanggal 10 Oktober 2019

Rifa'i, Muhammad. KH. Hasyim Asy'ari: Biografi singkat 1871-1947. Jogjakarta: Garasi 2010 
Rohani, Imam, "Pendidikan Karakter Dengan Pendekatan Tasawuf Modern Hamka Dan Tasawuf Transformatif Kontemporer," in Memperbincangkan Pemikiran Pendidikan Islam Dari Idealisme Substantif Hingga Konsep Aktual (Jakarta: Kencana, 2018).

Sudrajat, Akhmad.'Kompetensi Guru Dan Peran Kepala Sekolah”. Equilibrium, Vol.3. No.5. Januari-Juni 2007.

Sulo, Umar Tirtaraharja, Pengantar Pendidikan Jakarta: Rineka Cipta. 2005

Syukriya, Aini Ummu, Find Your Passion And Achieve Your Dream In 4.0 Era. Dalam Seminar Pendidikan IAIRM 15 Maret 2019.

Undang-undang Dasar Republik Indonesia nomor 20 Tahun 2003 tentang Sistem Pendidikan Nasional, Pasal 3 